\title{
Digestibility of guajillo for white-tailed deer
}

\author{
THOMAS G. BARNES, LYTLE H. BLANKENSHIP, LARRY W. VARNER, AND JAMES F. GALLAGHER
}

\begin{abstract}
A study was conducted from May 1986 to June 1987 with white-tailed deer (Odocoileus virginianus) to determine seasonal nutritive value and nutrient digestibilities of guajillo (Acacia berlandieri) and a pelleted diet. In vivo dry matter digestibility (DMD) of guajillo varied seasonally from 35.2 to $48.1 \%$ and was inversely correlated to levels of condensed tannins in the forage. Apparent protein digestibility varied seasonally from 13.7 to $45.8 \%$ and was a highly dependent function $\left(R^{2}=0.97\right)$ of the amount of neutral detergent fiber nitrogen (NDFN) digested and the negative impact of condensed tannins. Cellulose and hemicellulose digestibilities also varied seasonally (0.6 to $13.5 \%$ and 52.3 to $71.1 \%$, respectively). Nutrient digestibilities of the pelleted diet did not vary by season, sex, or age. Dry matter digestibility of the pelleted diet was $75.6 \% \pm 0.9$ and true protein digestibility was $95.0 \pm 0.04$. Results suggest summer is a stressful period for south Texas deer due to low protein and energy digestibility and high levels of condensed tannins.
\end{abstract}

Key Words: nutrition, Odocoileus, secondary plant compounds, tannins, Texas

South Texas white-tailed deer food habits and feeding preferences are well known (Chamrad and Box 1968, Everitt and Gonzalez 1979, Kie et al. 1980, Varner and Blankenship 1987). The proximate composition and in vitro DMD of deer forages have also been estimated (Varner et al. 1977, Everitt and Gonzalez 1979, Blankenship et al. 1982, Barnes et al. 1990). Relationships between food habits, chemical composition, and in vivo utilization of south Texas deer forages is largely unknown.

Deer in south Texas may consume over 160 plant taxa to meet their nutritional requirements (Chamrad and Box 1968). Forbs are selected whenever available (Kie et al. 1980); however, during much of the year and in drought years especially, the dietary staple of deer is browse (Varner and Blankenship 1987). Browse nutritional value, based on chemical analyses, often is overestimated. This overestimation is often attributed to the presence of condensed tannins, which reduce protein and dry matter digestibilities (Robbins et al. 1987a,b) and interfere with the interpretation of detergent fiber forage analysis (Reed 1986).

There are few data on the ability of deer to make effective use of tannin containing forage. There are also few data describing nutrient digestibility of southern shrubs. Therefore, we initiated this study to (1) gain a more complete understanding of shrub nutritive value, (2) understand the effect condensed tannins have on protein and energy digestion, and (3) complement previous research on food habits, proximate nutrient composition, and in vitro DMD of south Texas shrubs (Varner et al. 1977, Blankenship et al. 1982,

Authors are assistant extension professor, Department of Forestry, University of Kentucky, Lexington 40546-0073; retired professor, Texas Agricultural Experiment Station, Box 5520, Ulyade 77801; senior scientist, Purina Mills, 1401 S. Hanley Rd., St. Louis, MO 63088; and postdoctoral research assistant, Department of Forestry, University of California, Berkeley 94720 . At the time of research, authors were graduate research assistants and research" scientists, Department of Wildlife and Fisheries Sciences, Texas A\&M University, College Station 77843.

Research was supported by the Caesar Kleberg program in Wildlife Ecology at Texas A\&M University and the National Rifle Association of America. The assistance of T.J. Fillinger, G.M. Wampler, C. Hensarling, and T.J. VanNorman is appreciated. Appreciation is extended to C.T. Robbins for providing useful information on protein digestibility and A.N. Hagerman for conducting the protein precipitation procedure. D.E. Spalinger, F.C. Bryant, J. Reed, and F.A. Servello provided helpful comments on earlier drafts of this manuscript. This is contribution TA239900 of the Texas Agricultural Experiment Station.

Manuscript accepted 20 April 1990.
Varner and Blankenship 1987, Barnes et al. 1990). Answers to these questions would allow a more adequate determination of rangeland nutritional carrying capacity for white-tailed deer. Because many ranchers in south Texas feed deer a supplement year round, we also investigated in vivo nutrient digestibilities of a pelleted ration, thus determining the optimum period for supplementation.

\section{Methods}

The dietary importance of forage species studied was determined from published studies (Hughes 1982, Varner and Blankenship 1987) and examination of rumen contents of sacrificed deer from Dimmit, LaSalle, Maverick, Uvalde, and Zavala counties, Texas (Varner unpubl. data). Guajillo (Acacia berlandieri) is eaten by deer and cattle during all seasons and may constitute up to $37 \%$ of the diet (Hughes 1982, Varner and Blankenship 1987).

Guajillo stems, less than $7.0 \mathrm{~mm}$ in diameter, were removed by hand clippers from plants growing in shallow soils on the George Lyles Ranch in Zavala and Uvalde counties, Texas. Only current year's growth was collected to resemble deer browsing. This is important because deer usually select live tissue growing on stems less than $2.1 \mathrm{~mm}$ in diameter (Shafer 1963). Leaves were stripped from the stem by hand and fed fresh, or stored overnight under refrigeration and fed the following morning. It is important to feed fresh forages since handling affects the quantity of neutral detergent solubles and total phenolic compounds in the vegetation (Servello et al. 1987).

We conducted 5 seasonal, completely randomized balance trials using guajillo during the period June 1986 to April 1987. We also conducted 3 completely randomized balance trials using a pelleted diet (Table 1) during winter, spring, and summer 1986. A trial using

Table 1. Commercially prepared pelleted ration fed to white-tailed deer used in metabolism studies.

\begin{tabular}{lc}
\hline \hline Ingredient & Percent composition \\
\hline Cottonseed meal & 29.3 \\
Alfalfa meal & 24.2 \\
Corn & 19.5 \\
Milo & 10.3 \\
Molasses & 7.3 \\
Calcium carbonate & 2.4 \\
Bentonite & 2.4 \\
Dicalcium phosphate & 2.4 \\
Sodium chloride & 1.0 \\
Auromycin & 0.5 \\
Vitamin A & 0.25 \\
\hline
\end{tabular}

the pelleted diet was not conducted during the fall because this is not a nutritionally stressful period for deer. Experimental animals were born in captivity, hand-reared on evaporated milk and calf starter, and thereafter maintained on a nutritionally complete pelleted ration supplemented with browse, alfalfa, or native hay, and field corn. A mixture of adult $(>2.5$ years of age) male and female animals, that were well acclimated to metabolism crates, were used in trials with guajillo because there were no differences in pelleted diet nutrient digestibilities attributed to sex.

Deer $(\mathrm{N}=6)$ were confined in $1.2 \times 1.2 \times 1.2 \mathrm{~m}$ metabolism crates that were housed in a climate-controlled room. Temperatures closely approximated outdoor conditions except in summer, 
when daytime temperatures never exceeded $27^{\circ} \mathrm{C}$. Animals were weighed prior to each trial, which consisted of a 5-day adjustment period followed by a 5-day total fecal and urine collection period. While 7-day adjustment periods are recommended for reduction of variance in the data (Mothershead et al. 1972), we used a 5-day period because the animals were supplemented with browse prior to each trial, were previously conditioned to the crates, maintained maximal intakes, were not anesthetized, and it was less stressful on the animals. Schneider and Flatt (1975) reviewed the literature and concluded a 5-day pretrial period for cattle was adequate if all that is necessary is to change residual plant materials. They also concluded that longer collection periods result in more precision but may increase bias due "to accident, animal sickness, feed refusal, or other disturbing factors". Holloway et al. (1981), therefore, used a 7-day preliminary trial followed by a 5-day collection period for cattle eating fresh forage. Because deer have significantly faster passage rates than cattle (Huston et al. 1986), a shorter pretrial period should be adequate to remove residual vegetative matter. At worst, a short pretrial period would result in decreased precision and failure to detect the relationships that exist with a decreased possibility of bias (Holloway et al. 1981). Subsequent in vitro DMD data were highly correlated with in vivo DMD values (Barnes et al. 1989).

Forage was offered ad libitum during the pretrial period and fed at maximal consumption levels during the collection period. Deer were fed once in the morning and water was provided ad libitum during all experiments.

Forage, orts, and fecal samples were taken daily, oven-dried at $60^{\circ} \mathrm{C}$, composited for the total collection period, ground through a $1-\mathrm{mm}$ screen in a Wiley Mill, and subsampled for analyses. Urine was collected daily in opaque plastic containers, acidified with $20 \%$ HCL, subsampled, and frozen until analyzed. All samples were analyzed for proximate nutrients, fiber, and gross energy. Gross energy was determined using a Parr adiabatic oxygen bomb calorimeter. All samples were digested following Adler and Wilcox's (1985) perchloric acid and hydrogen peroxide technique (modified by Gallagher, personal communication). Crude protein $(N \times 6.25)$ was determined colorimetrically on the wet-digested samples (Laubner 1975). Condensed tannins were extracted in methanol and measured colorimetrically using a catechin standard (Burns 1971). Precipitable protein $\left(\mathrm{cm}^{2} / \mathrm{mg}\right)$, due to the effects of condensed tannins, was also measured (Hagerman 1987).

Forage and feces were analyzed using detergent analyses (Goering and Van Soest 1970) without the addition of sodium sulfite (Mould and Robbins 1981). Lignin was determined by sequential treatments of acid detergent fiber (ADF) with potassium permangenate. Cellulose and hemicellulose were determined by difference. Nitrogen (Laubner 1975) in NDF of feed and feces was also measured.

Digestible energy (kcal/g) was calculated by multiplying gross
Table 2. Mean body weight (BW) and dry matter intakes (DMI) of whitetailed deer used in metabolism studies.

\begin{tabular}{llclcl}
\hline \hline Diet & N & Weight & SE & \multicolumn{2}{c}{ DMI/kgBW SE } \\
\hline & & $(\mathrm{kg})$ & & $(\mathrm{g} /$ day) \\
Guajillo Spring & 5 & 43.7 & 2.1 & $11.7 \mathrm{~A}^{1}$ & 1.4 \\
Early summer & 5 & 49.3 & 2.4 & $13.0 \mathrm{~A}$ & 1.9 \\
Late summer & 5 & 30.5 & 1.0 & $19.6 \mathrm{~B}$ & 2.5 \\
Fall & 6 & 36.8 & 1.0 & $13.3 \mathrm{~A}$ & 1.8 \\
Winter & 5 & 41.1 & 2.0 & $20.0 \mathrm{~B}$ & 1.5 \\
Pelleted & $7(\mathrm{~A})^{2}$ & 43.7 & 1.3 & 21.0 & 0.6 \\
& $4(\mathrm{Y})$ & 25.1 & 0.7 & 32.4 & 1.3 \\
\hline
\end{tabular}

IValues within a column followed by different letters are different $(P \leq 0.05)$.

'Indicates a difference $(P \geq 0.05)$ in $\mathrm{DMI} / \mathrm{kgBW}$ between adult $(\mathrm{A})$ and yearling (Y) white-tailed deer.

energy intake $X$ apparent digestibility. Expected digestible protein in feed was calculated using the equation $\mathrm{Y}=-3.87+0.9387 \mathrm{X}$ based on nonphenolic-containing forages fed to deer (Robbins et al. 1987a). Observed digestible protein was calculated by multiplying CP intake $X$ apparent digestibility (Robbins et al. 1987a). Protein reduction was calculated as the difference between expected and observed digestible protein. True protein digestiblity of the pelleted diet was calculated using a metabolic fecal nitrogen value of $4.88 \mathrm{~g} / 100 \mathrm{~g}$ feed (Robbins et al. 1974). This source of endogenous nitrogen was removed from digestibility equations.

True protein digestibility of guajillo was estimated by replacing total nitrogen in the feces with fecal nitrogen insoluble in neutral detergent (Mason 1969, Van Soest 1967) because fecal nitrogen that is insoluble in neutral detergent originates from indigestible feed nitrogen; whereas, fecal nitrogen that is soluble in neutral detergent is from microbial and endogenous sources of nitrogen in the digestive tract. A Lucas test (Van Soest 1982) was not used to predict true protein digestibility because the use of regression equations from a Lucas test for uniformity of protein is invalid when applied to feeds that contain tannins (Reed et al. 1990).

Unbalanced one-way analysis of variance and the least significant differences mean comparison tests were used to detect differences in browse nutrient digestibilities. Analysis of variance was also used to determine differences in nutrient digestibilities between pelleted ration trials. A Student's $t$ test was used to detect differences in dry matter intake (DMI) and nutrient digestibilities of the pelleted ration by yearling and adult deer. Significance is indicated at the 0.05 level of probability.

\section{Results and Discussion}

One individual deer during each trial, except during fall, went off feed and had to be removed from the metabolism crate (Table 2). Mean deer weight ( $39.4 \mathrm{~kg}$ ) was not different between trials (Table 2). Deer consumed significantly less guajillo during the spring, early summer, and fall periods and DMI/ $\mathrm{kg}$ body weight (BW)/day

Table 3. Protein, energy, and neutral detergent fiber (NDF) composition (100\% dry matter basis) of forages fed to south Texas white-triled deer in digestion studies.

\begin{tabular}{|c|c|c|c|c|c|c|c|c|c|c|}
\hline Diet & $\begin{array}{c}\text { Crude } \\
\text { protein }\end{array}$ & $\begin{array}{c}\text { Digestible } \\
\text { protein }\end{array}$ & $\begin{array}{c}\text { Protein } \\
\text { precipitation }\end{array}$ & $\begin{array}{c}\text { Digestible } \\
\text { energy }\end{array}$ & $\begin{array}{c}\text { Condensed } \\
\text { tannins }\end{array}$ & NDF & Cellulose & $\begin{array}{c}\text { Hemi- } \\
\text { cellulose }\end{array}$ & Lignin & NDFN \\
\hline & $(\%)$ & $\begin{array}{l}(g / 100 g) \\
\text { feed }\end{array}$ & $(\mathrm{cm} 2 / \mathrm{mg})$ & (kcal/g) & $(\mathrm{mg} / \mathrm{g})$ & $(\%)$ & $(\%)$ & $(\%)$ & $(\%)$ & $\begin{array}{l}(\% \text { of }) \\
\text { total N }\end{array}$ \\
\hline $\begin{array}{l}\text { Guajillo } \\
\text { spring } \\
\text { Early }\end{array}$ & 20.0 & 9.14 & 0.220 & 2.27 & 92.1 & 57.4 & 15.9 & 30.4 & 11.9 & 49.4 \\
\hline \begin{tabular}{l}
\multicolumn{1}{c}{ summer } \\
Late summer \\
Fall \\
Winter
\end{tabular} & $\begin{array}{l}20.2 \\
15.6 \\
16.8 \\
17.6\end{array}$ & $\begin{array}{l}7.31 \\
2.14 \\
3.51 \\
4.01\end{array}$ & $\begin{array}{l}0.161 \\
0.228 \\
0.206 \\
0.196\end{array}$ & $\begin{array}{l}1.91 \\
1.60 \\
1.75 \\
1.93\end{array}$ & $\begin{array}{r}89.9 \\
112.8 \\
108.1 \\
117.9\end{array}$ & $\begin{array}{l}50.9 \\
50.8 \\
53.8 \\
59.2\end{array}$ & $\begin{array}{l}16.8 \\
18.5 \\
18.9 \\
20.1\end{array}$ & $\begin{array}{l}24.4 \\
20.0 \\
24.6 \\
25.7\end{array}$ & $\begin{array}{l}10.8 \\
11.9 \\
10.4 \\
12.8\end{array}$ & $\begin{array}{l}46.2 \\
52.8 \\
52.7 \\
54.0\end{array}$ \\
\hline
\end{tabular}


Table 4. Mean digestibility coefficients (\% of dry matter) of forages fed to south Texas white-tailed deer used in metabolism studies.

\begin{tabular}{|c|c|c|c|c|c|c|c|c|c|c|}
\hline \multirow[b]{2}{*}{ Diet } & \multicolumn{2}{|c|}{ Dry matter } & \multicolumn{2}{|l|}{ Energy } & \multicolumn{2}{|c|}{ Apparent protein } & \multicolumn{2}{|c|}{ True protein } & \multicolumn{2}{|c|}{ NDF } \\
\hline & $\overline{\bar{x}}$ & SE & $\overline{\bar{x}}$ & SE & $\bar{x}$ & SE & $\overline{\bar{x}}$ & SE & $\overline{\bar{x}}$ & $\mathrm{SE}$ \\
\hline Guajillo spring & $48.1 \mathrm{C}^{1}$ & 0.8 & $46.0 \mathrm{C}$ & 0.9 & $45.8 \mathrm{~B}$ & 2.2 & $56.8 \mathrm{D}$ & 0.9 & $22.8 \mathrm{~B}$ & 1.8 \\
\hline Early summer & $41.2 \mathrm{AB}$ & 2.7 & $39.1 \mathrm{~B}$ & 2.8 & $35.5 \mathrm{~B}$ & 4.1 & $51.1 \mathrm{CD}$ & 2.3 & $7.6 \mathrm{~A}$ & 4.5 \\
\hline Late summer & $35.2 \mathrm{~A}$ & 2.4 & $32.5 \mathrm{~A}$ & 2.7 & $13.7 \mathrm{~A}$ & 3.5 & $38.0 \mathrm{~A}$ & 2.3 & $0.0 \mathrm{~A}$ & 3.5 \\
\hline Fall & $38.3 \mathrm{AB}$ & 2.3 & $35.9 \mathrm{AB}$ & 2.3 & $20.5 \mathrm{~A}$ & 5.2 & $43.0 \mathrm{AB}$ & 1.8 & $6.7 \mathrm{~A}$ & 3.1 \\
\hline \multirow[t]{2}{*}{ Winter } & 41.5D & 0.6 & $38.6 \mathrm{AB}$ & 0.7 & $22.7 \mathrm{~A}$ & 2.5 & $46.6 \mathrm{BC}$ & 1.6 & 17.9B & 1.2 \\
\hline & \multicolumn{2}{|c|}{ Cellulose } & \multicolumn{3}{|c|}{ Hemicellulose } & \multicolumn{2}{|c|}{ NDFN } & \multicolumn{3}{|c|}{ Condensed tannins } \\
\hline Diet & $\overline{\bar{x}}$ & $\overline{S E}$ & $\overline{\bar{x}}$ & & SE & $\overline{\bar{x}}$ & SE & & $\overline{\bar{x}}$ & $\overline{\text { SE }}$ \\
\hline Guajillo spring & $0.6 \mathrm{~A}$ & 3.6 & $71.1 \mathrm{C}$ & & 1.9 & $34.5 B$ & 2.4 & & $92.7 \mathrm{C}$ & 0.4 \\
\hline Early surnmer & $6.5 \mathrm{AB}$ & 3.2 & $65.6 \mathrm{BC}$ & & 3.2 & $26.2 \mathrm{~B}$ & 5.1 & & $84.8 \mathrm{~A}$ & 0.7 \\
\hline Late summer & $11.1 \mathrm{~B}$ & 4.3 & $52.3 \mathrm{~A}$ & & 3.5 & $14.5 \mathrm{~A}$ & 2.4 & & $82.6 \mathrm{~A}$ & 1.4 \\
\hline Fall & $5.9 \mathrm{AB}$ & 3.2 & $62.1 \mathrm{~B}$ & & 2.5 & $17.1 \mathrm{~A}$ & 3.1 & & $84.2 \mathrm{~A}$ & 1.1 \\
\hline Winter & $13.5 \mathrm{~B}$ & 1.4 & $67.9 \mathrm{BC}$ & & 1.6 & $16.8 \mathrm{~A}$ & 1.3 & & 88.4B & 0.8 \\
\hline
\end{tabular}

of adult deer consuming guajillo averaged $15.5 \mathrm{~g} / \mathrm{kg} \mathrm{BW} /$ day. Yearling deer, consuming the pelleted ration, had significantly higher DMI $/ \mathrm{kg} \mathrm{BW} /$ day than adults (Table 2). Differences in voluntary intake were expected and are determined by a range of behavioral, morphological, and physiological mechanisms linked to photoperiod and endocrine changes (Allison 1985). Intake levels reported in our study are similar to levels reported in previous studies using mule deer (Odocoileus hemonius) or white-tailed deer (Baker and Hobbs 1987, Mautz et al. 1976).

No statistical seasonal comparisons of forage quality could be made because daily feed samples were taken for each deer from a common forage supply and composited for analysis. Gross energy of guajillo was similar and averaged $4.7 \pm 0.87 \mathrm{kcal} / \mathrm{g}$ (Table 3). Digestible energy (DE) averaged $1.89 \mathrm{kcal} / \mathrm{g}$ and varied seasonally. Dry matter digestibility of guajillo varied seasonally and averaged 40.8\% (Table 3). Condensed tannins were inversely correlated to $\mathrm{DMD}\left(\mathrm{Y}=63.1-0.2 \mathrm{X}, \mathrm{R}^{2}=0.60\right)$ but not to NDF digestibility $(\mathrm{Y}=$ $32.2-0.2 X, R^{2}=0.20$ ). The lack of relationship between condensed tannins and NDF digestibility is not surprising because condensed tannins appear to elevate NDF content as a result of insoluble complexes being formed with protein and carbohydrates (Reed 1986).

Dry matter digestibility is an important nutritional variable to measure since it provides a strong and direct inference to energy utilization within the animal (Barnes et al. 1989). White-tailed deer have been classified as concentrate selectors (Hanley 1982) which dictates energy should come from fermentation of cell solubles. These solubles should be $100 \%$ digestible (Van Soest 1982) unless phenolics or volatile oils are present. We observed a reduction of 18 to $34 \%$ (from theoretical limit of 98 to $100 \%$ digestible) in the digestibility of cell solubles. The inverse relationship between DMD and concentration of condensed tannins and reduction in theoretical digestible cell solubles indicate condensed tannins exert their primary influence through reducing digestible cell solubles (Robbins et al. 1987b) and not by reducing cell wall digestibility (Barry and Manley 1984, Barry et al. 1986). However, without quantifying changes in condensed tannin solubilities and their effects on fiber analysis, it is difficult to pinpoint cause and effect (Reed 1986) especially since condensed tannins can complex with protein to elevate NDFN (Reed and Soller 1987), a substantial proportion of NDF.

Cellulose digestibilities were low (0.6-13.5\%) for guajillo and were lowest during the spring (Table 4). Hemicellulose digestibility varied seasonally and averaged $63.7 \%$. Hemicellulose digestibility was lowest during late summer. The highly variable and low digestibility of cell wall fractions may be attributed to insoluble complexes formed with condensed tannins which interfere with the detergent analysis system (Reed 1986).

Digestion of cell wall components, especially if highly lignified (mean lignin content of guajillo was $11.6 \pm 0.17 \%$ ), is a slow process. Fiber available for conversion into energy are cellulose and hemicellulose with the upper digestion limit set by lignin, cutin, and silica content. Because tannins appear to form insoluble protein and carbohydrate complexes, NDF may not be an accurate measure of cell wall in browse (Reed 1986). However, our data indicate that hemicellulose is digested more easily by deer than is cellulose or that the microbial population was better adapted for digesting hemicellulose (52.3-71.1\%) digestible) than cellulose (0.6-13.5\% digestible) which is consistent with predictions for a concentrate selector (Kay et al. 1980). Passage rate ultimately determines fiber digestion (Huston et al. 1986). These factors (passage rate, low cellulose digestion, and tannin formed insoluble complexes) might have accounted for the low DMD of guajillo during the late summer and fall periods especially since passage rate of guajillo is fastest during the late summer period (Barnes et al. 1991).

Digestibility of condensed tannins varied seasonally (Table 4) and was higher than expected. These high digestibilities may be attributed to minimal recovery of condensed tannins in the feces because they had complexed with protein and carbohydrates upon passage through the digestive tract and were no longer soluble (Reed and Soller 1987).

The $\mathrm{CP}$ of guajillo was highest during periods of active growth in the spring and early summer, declined in late summer, then increased in response to new growth in the fall (Table 3). A substantial portion of total nitrogen was bound to NDF (range 46.2 to $54.0 \%, \ddot{x}=50.3 \%$ ). There was no significant relationship between digestible protein reduction and protein precipitation measured using the ring diameter squared method (Table 3). Availability of apparently digestible protein in the browse diets was reduced from expected digestible protein of nonphenolic containing forages (Robbins et al. 1987a) by 3.5 to $8.5 \%$. Digestible protein reduction was highly correlated to condensed tannin concentration in the diet $\left(Y=-2.4+0.1 X, R^{2}=0.86\right)$. Reed et al. (1990) observed a theoretical reduction in protein availability of $35 \%$ (compared to an average of $88 \%$ in nontannin containing uniform feeds (Van Soest 
1982)) in a tanniniferous Acacia. They suggested lower apparent and true protein digestibility was related to a high excretion of fecal NDFN. The high excretion of fecal NDFN could be attributed to the presence of phenols which complex with protein and caused an increase in apparent lignin content of the feces, leading to negative digestibility of lignin and NDFN (Reed 1986).

True protein digestibility varied seasonally and is considerably lower than true protein digestibility of uniform feeds (approximately $88 \%$, Van Soest 1982 ) such as the pelleted diet (95.0\%). This lowered digestibility can be attributed to the presence of phenolics (Reed et al. 1990) that reduce protein availability (Robbins et al. 1987a) and cause the nitrogen to form insoluble complexes with fiber (Reed 1986). These complexes result in elevated fecal NDFN digestibility coefficients. Reed and Soller (1987) observe that phenolics increase the amount of endogenous nitrogen, including urea, recycled to the rumen which increased microbial utilization of endogenous nitrogen.

Digestible or available protein, not CP content of the forage, is the nutritionally important factor in meeting animal requirements. Available protein is a function of the total amount of CP present minus the indigestible NDFN and the extent of protein precipitation by tannins (Robbins et al. 1987a). A large part of the variability in protein digestibility of guajillo appears related to the presence of condensed tannins. Digestible protein reduction (compared to expected digestible protein in nonphenolic forages) of 3.5 to $8.5 \%$ in the browse diets agrees with values obtained by Robbins et al. (1987a). Deer may be able to avoid these effects behaviorally by selection of older, less toxic stems (Provenza and Malechek 1984), increasing DMI, or selection of nonphenolic forages (Bryant and Kuropat 1980). Nonphenolic forages are often scarce in south Texas during the summer or extended periods of drought. Deer may also minimize nitrogen loss by complexing tannin with salivary glycoprotein (Austin et al. 1989).

The remaining variability in apparent digestible protein of guajillo is a result of the amount of NDFN in the forage and NDFN digestibility. This source of nitrogen becomes available only if NDF can be digested. Small quantities of NDF and subsequently small amounts of NDFN were digested by deer in this study. However, condensed tannins can interfere with fiber analysis by forming insoluble complexes (Reed 1986) and NDF and NDFN digestibility may be greater than reported. The CP content of the browse rations were well above the 6 to $8 \%$ required for minimal ruminal function, but available protein became low as the forages matured and tannin levels increased. Protein precipitation during the late summer and fall periods was exacerbated due to low quantities of NDFN being digested, which may be a function of rapid passage of fiber particles (Barnes et al. 1991) or tanninprotein complexes (Reed 1986, Reed et al. 1990).

There were no seasonal differences in nutrient digestibility between pelleted diet trials. Consequently, data were pooled and tested for differences attributed to age and sex. There were no digestibility differences attributed to age or sex, consequently data were pooled. Gross energy of the pelleted diet was $3.8 \mathrm{kcal} / \mathrm{g}$, whereas digestible energy was $2.96 \mathrm{kcal} / \mathrm{g}$. Dry matter digestibility of this diet was $75.6 \pm 0.9 \%$. Neutral detergent fiber, cellulose, and hemicellulose digestibilities were $81.7 \pm 0.7,62.0 \pm 1.6$, and $93.5 \pm$ 0.5 , respectively. This diet is an excellent source of energy. The pelleted diet contained $22.5 \% \mathrm{CP}$ and had $21.62 \mathrm{~g} / 100 \mathrm{~g}$ feed digestible protein. True protein digestibility of this diet was $95.0 \pm$ $0.04 \%$. The true protein digestibility of this diet is in close agreement with that found in other studies indicating deer are not different from domestic ruminants in their ability to digest protein in nonphenolic forages (Robbins et al. 1974).

Our information indicates white-tailed deer meet their relatively high weight specific metabolic requirements through digestion of neutral detergent solubles, consistent with current ecological foraging theory of small ungulates. Late summer is the most stressful nutritional period for deer in south Texas due to low DMD, $D E$, and digestible protein in browse, which is a function of increased condensed tannins and low NDF digestibilities. This is the period when supplementation with the pelleted ration could have its greatest impact because this diet was highly digestible, containing approximately $3 \mathrm{kcal} / \mathrm{g} \mathrm{DE}$, and $21 \mathrm{~g} / 100 \mathrm{~g}$ digestible protein. The nutritional value of any forage should not be explained using a 1-dimensional approach such as proximate analyses, digestibility, rate of digestion and passage, or phenolic content. More research on the effects condensed tannins have on protein metabolism, rumen microorganisms, and ruminant digestive enzymes is needed to better predict the nutritive value of forages containing secondary plant compounds. We present information that indicates complex relationships exist between intake, nutrient digestibilities, and secondary plant compounds.

\section{Literature Cited}

Adler, R.R., and J.E. Wilcox. 1985. Rapid perchloric acid digest methods for analysis of major elements in plant tissue. Commun. in Soil Sci. Plant Anal. 16:1153-1163.

Allison, C.D. 1985. Factors affecting forage intake by range ruminants: $A$ review. J. Range Manage. 38:305-311.

Austin, P.J., L.A. Suchar, C.T. Robbins, and A.E. Hagerman. 1989. Tannin-binding proteins in saliva of deer and their absence in saliva of sheep and cattle. J. Chem. Ecol. 15:1335-1347.

Baker, D.L., and N.T. Hobbs. 1987. Strategies of digestion and digestive efficiency and retention time of forage diets in montane ungulates. Can. J. Zool. 65:1978-1984.

Barnes, T.G., L.W. Varner, L.H. Blankenship, and J.F. Gallagher. 1989. Predicting in vivo dry matter, energy, and protein digestibility of deer forages. Proc. Annu. Conf. Southeast. Fish and Wildl. Agencies. 43:297-305.

Barnes, T.G., L.W. Varner, L.H. Blankenship, T.J. Fillinger, and S.C. Heineman. 1990. Macro and micro mineral content of south Texas deer forages. J. Range Manage. 43:220-223.

Barnes, T.G., L.W. Varner, L.H. Blankenship, and J.F. Gallagher. 1991. Indigestible particulate passage in white-tailed deer. In: (R.D. Brown, ed) Proc. Second Internat. Symp. on the Biol. of Deer. Academic Press, New York, In Press.

Barry, T.N., and T.R. Manley. 1984. The role of condensed tannins in the nutritional value of Lotus pedunculatus for sheep. 2. Quantitative digestion of carbohydrate and proteins. Brit. J. Nutr. 51:493-504.

Barry, T.N, T.R. Manley, and S.J. Duncan. 1986. The role of condensed tannins in the nutritional value of Lotus pedunculatus for sheep .4. Sites of carbohydrate and protein digestion as influenced by dietary reactive tannin concentration. Brit. J. Nutr. 55:123-137.

Blankenship, L.H., L.W. Varner, and G.W. Lynch. 1982. In vitro digestibility of south Texas range plants using inoculum from four ruminant species. J. Range Manage. 35:664-666.

Bryant, J.P., and P.J. Kuropat. 1980. Selection of winter forage by subartic browsing vertebrates: The role of plant chemistry. Annu. Rev. Ecol. Syst. 11:261-285.

Burns, R.E. 1971. Methods for estimation of tannin in grain Sorghum. Agron. J. 63:511-512.

Chamrad, A.D., and T.W. Box. 1968. Food habits of white-tailed deer in south Texas. J. Range Manage. 21:158-164.

Everitt, J.H., and C.L. Gonzalez. 1979. Botanical composition and nutrient content of fall and early winter diets of white-tailed deer in south Texas. Southwest. Natur. 24:297-310.

Goering, H.K., and P.J. Van Soest. 1970. Forage analyses (apparatus, reagents, procedures and some applications). USDA Agr. Handb. 379.

Hanley, T.A. 1982. The nutritional basis for food selection by ungulates. J. Range Manage. 35:146-151.

Hagerman, A.E. 1987. Radial diffusion method for determining tannin in plant extracts. J. Chem. Ecol. 13:437-449.

Holloway, J.W., R.E. Estell, II, and W.T. Butts. 1981. Relationship between fecal components and forage consumption and digestibility. $\mathrm{J}$. Anim. Sci. 52:836-843.

Hughes, H.G. 1982. Estimated energy, protein, and phosphorus balances of a south Texas white-tailed deer population. Ph.D. Thesis, Texas A\&M Univ., College Station. 
Huston, J.E., B.S. Rector, W.C. Ellis, and M.L. Allen. 1986. Dynamics of digestion in cattle, sheep, goats, and deer. J. Anim. Sci. 62:208-215.

Kay, R.N.B., W.V. Englehardt, and R.G. White. 1980. The digestive physiology of wild ruminants. In: (Y. Ruckebusch and P. Thivend, eds.) Digestive physiology of wild ruminants. A.V.I. Westport, Conn.

Kie, J.G., D.L. Drawe, and G. Scott. 1980. Changes in diet and nutrition with increased herd size in Texas white-tailed deer. J. Range Manage. 33:28-34.

Laubner, K. 1975. Photometric determination of nitrogen. Wet incineration of indophenol blue with salicylate/hypochlorite. Clinica Chimica Acta 67:107-110.

Mason, V.C. 1969. Some observations on the distribution and origin of nitrogen in sheep faeces. J. Agr. Sci. 73:99-111.

Mautz, W.W., H. Silver, J.B. Holter, H.H. Hayes, and W.E. Urban, Jr. 1976. Digestibility and related nutritional data for seven northern deer browse species. J. Wildl. Manage. 40:630-638.

Mothershead, C.L., R.L. Cowan, and A.P. Ammann. 1972. Variations in determinations of digestive capacity of the white-tailed deer. J. Wildl. Manage. 36:1052-1060.

Mould, E.D., and C.T. Robbins. 1981. Evaluation of detergent analysis in estimating nutritional value of browse. J. Wildl. Manage. 45:937-947.

Provenza, F.D., and J.C. Malechek. 1984. Diet selection by domestic goats in relation to blackbrush twig chemistry. J. Appl. Ecol. 21:831-841.

Reed, J.D. 1986. Relationships among soluble phenolics, insoluble proanthocyanidins and fiber in East African browse species. J. Range Manage. 39:5-7.

Reed, J.D., and H. Soller. 1987. Phenolics and nitrogen utilization in sheep fed browse. P. 47-48. In: (M. Rose, ed.) Herbivore nutrition research: Research papers presented at the Second Internat. Symp. on the Nutrition of Herbivores. Dept. of Primary Industries, Wool Biol. Lab., Yeerongpilly. Qld. 4067.
Reed, J.D., and H. Soller, and A. Woodward. 1990. Fodder tree and straw diets for sheep: intake, growth, digestibility and the effects of phenolics on nitrogen utilization. Anim. Feed Sci. and Technology 30:39-50.

Kobbins, C.T., R.L. Prior, A.N. Moen, and W.J. Visek. 1974. Nitrogen metabolism of white-tailed deer. J. Anim. Sci. 38:186-191.

Robbins, C.T., T.A. Hanley, A.E. Hagerman, O. Hjieljord, D.L. Baker, C.C. Schwartz, and W.W. Mautz. 1987a. Role of tannins in defending plants against ruminants: reduction in protein availability. Ecology 68:98-107.

Robbins, C.T., S. Mole, A.E. Hagerman, and T.A. Hanley. 1987b. Role of tannins in defending plants against ruminants: reduction in dry matter digestion. Ecology 68:1606-1615.

Schneider, B.H., and W.P. Flatt. 1975. The evaluation of feeds through digestibility experiments. The Univ. Georgia Press, Athens.

Servello, F.A., R.L. Kirkpatrick, and K.E. Webb, Jr. 1987. Predicting metabolizable energy in the diet of ruffed grouse. J. Wildl. Manage. 51:560-567.

Shafer, E.L. 1963. The twig-count method for measuring hardwood deer browse. J. Wildl. Manage. 27:428-438.

Van Soest, P.J. 1967. Development of a comprehensive system of feed analyses and its application to forages. J. Anim. Sci. 26:119-128.

Van Soest, P.J. 1982. Nutritional ecology of the ruminant. O \& B Books, Corvallis, Ore.

Varner, L.W., and L.H. Blankenship. 1987. South Texas shrubs: Nutritive value and utilization by herbivores. P. 108-112. In: Proc. Symp. on Plant Herbivore Interactions. USDA Forest Serv. Gen. Tech. Rep. INT-222.

Varner, L.W., L.H. Blankenship, and G.W. Lynch. 1977. Seasonal changes in nutritive value of deer food plants in south Texas. Proc. Annu. Conf. Southeast. Assoc. Fish and Wildl. Agencies 31:99-106. 